\title{
PENGARUH PEMBERITAAN MEDIA MASA PADA KASUS DUGAAN KORUPSI DAN PARTISIPASI WARGA DALAM MENGGUNAKAN HAK PILIH DI PEMILUKADA SERENTAK DI INDONESIA
}

\author{
Gede Moenanto Soekowati \\ Dosen Ilmu Komunikasi Universitas Pancasila \\ moenanto@gmail.com
}

\begin{abstract}
Democracy in Indonesia is steping forward and developing currently that could be seen through the general election from regional to national level. The development of democracy has been also influenced by media, in this context, media could mean the extension of people. Media include mass media, social media, and online media. The influence of media in society as a tool for participating for the general election and democracy could not be denied. The influence of media could be interfered by some parties such as politics, governments, and departments of law for justice. Those influence are not simply to demonstrate, but the implications are both explicitly and implicitly influence the communities in the way they participate in for using their right in the general election.
\end{abstract}

Keywords: $\quad$ media, election, democracy, influence

\begin{abstract}
Abstrak
Demokrasi di Indonesia melangkah dan berkembang di mana tercipta dengan pemilihan umum di tingkat regional dan nasional. Perkembangan demokrasi juga dipengaruhi oleh media, di negara ini, media berarti perpanjangan manusia. Media adalah media massa, media sosial, dan media online. Pengaruh media bagi rakyat dalam arti ikut serta untuk pemilihan umum dan demokrasi tentunya memiliki pengaruh yang sangat besar. Pengaruh oleh media juga dipengaruhi oleh pihak lain seperti partai politik, pemerintah, dan departemen hukum untuk keadilan. Pengaruh itu tidak mudah untuk dijelaskan, tetapi pengaruhnya secara langsung dan tidak langsung bagi orang-orang untuk berpartisipasi menggunakan hak mereka untuk memilih yang terjadi untuk tindakan mereka.
\end{abstract}

Kata kunci: media, pemilu, demokrasi, pengaruh 


\section{Pendahuluan}

Pelaksanaan pemilihan umum kepala Daerah (Pemilukada) langsung di tahun 2017 dan tahun 2018 menunjukkan fenomena terkait persaingan di antara sejumlah kandidat diwarnai dengan persaingan partai politik (parpol) untuk meraih kemenangan. Pemilukada di sejumlah daerah juga diwarnai dengan upaya penegakan hukum oleh Komisi Pemberantasan Korupsi (KPK), meski diketahui, terdapat potensi mahalnya biaya pemilukada yang bermuara pada tingginya modal yang harus dikeluarkan sejumlah kandidat.

Meski demikian, upaya penegakan hukum telah dilakukan KPK dengan tindakan yang sangat keras di mana sejumlah kepala daerah meringkuk di penjara. Bahkan, Ketua Mahkamah Konstitusi (MK), Akil Mochtar pun ditangkap gara-gara penyuapan terkait dengan kasus pemilukada yang ditangani oleh MK.Seperti halnya Bupati terpilih Wonosobo adalah anak juragan kayu terbesar. Dia adalah kepala daerah yang dinilai tidak bisa apa-apa, termasuk gagap bicara di depan publik. Sang ayah membeli kursi bupati untuk anaknya, konon mengeluarkan biaya sampai Rp 40 miliar.(https://nasional.kompas.com/read/2014/12/27).

Pada sejumlah kasus pemilukada, jauh lebih banyak yang tidak baik karena kepala daerah itu terjerat kasus korupsi. Maka dari itu, gairah masyarakat terhadap pelaksanaan pemilukada pun menjadi tidak sebaik pada awal-awal pelaksanaan pemilukada langsung yang dilaksanakan di Indonesia. Apalagi, terdapat ketegangan-ketegangan dalam sejumlah pelaksanaan pemilukada langsung tersebut.

Data Kemendagri, dari sekitar 500 kepala daerah, lebih dari 350 diantaranya tersangkut korupsi. Meskipun demikian, pemberian kata korupsi itu masih cenderung bisa diperdebatkan, tapi korupsi yang menjerat kepala daerah itu tidak bisa dipungkiri telah mengakibatkan banyaknya kasus korupsi yang diketahui publik melalui pemberitaan di media massa. 
Dalam sejumlah pemilukada yang telah berlangsung dan akan berlangsung, mereka yang terjerat dugaan korupsi itu demikian banyak. Potensi berbagai kalangan untuk melakukan korupsi sudah diketahui. Kasus korupsi lainnya melibatkan Bupati Bangkalan di mana bapaknya merupakan terpidana korupsi. Bupati Bangkalan adalah seorang bupati 'in absentia' karenatidak pernah masuk kantor. Sudah terjadi upaya untuk melengserkan, namun gagal karena dia bisa bayar hampir semua parpol. Ada juga fenomena para penjudi yang bisa menentukan hasil pilkada. Fenomena ini marak terjadi di Jawa Timur. Ada fenomena yang menarik dari masyarakat $\square$ dalam merespon pilkada langsung di daerah Wonosobo, bahwa adaseorang ibu menolak uang dari calon B. Dengan alasan "Saya sudah menerima uang dari calon A. Sebagai orang Islam saya harus menjaga amanah. Dosa kalau mengingkari janji." Ungkapan Ini contoh dari merasuknya money politics dan pemahaman yang kurang di kalangan masyarakat. Mereka seperti tidak tahu bahwa menerima uang dari calon mana saja, sebenarnya dosa atau salah. Betul, ada kepala daerah yang progresif dan inovatif. Namun, masih banyak yang belum bagus. Kalau saja ada penelitian mendalam dengan sampel 100 pilkada, kita mungkin bisa mengetahui berbagai masalah dan dicari solusinya. Tidak cuma jajak pendapat kalahmenang. Salah satu tugas wartawan juga untuk tidak terjebak dalam horse race journalism, ketika meliput politik.

Fenomena lain yang terjadi di daerah Jawa Timur khususnya Banyuwangi bahwa kebijakan progresif kepala daerah, tidak boleh adanya buah impor, supaya buah lokal tetap laku di masyarakat, dimana para petani buah akan menadapatkan keuntungan yang lebih banyak. Yang kemudian diikuti oleh para pengusaha hotel bintang jaringan internasional yang juga dibatasi dan mereka diwajibkan menggunakan dana Corporate Social Responsibility (CSR) sebagai konsep bahwa organisasi, khususnya, perusahaan adalah memiliki berbagai bentuk tanggung jawab terhadap seluruh pemangku kepentingannya, yang di antaranya adalah konsumen, untuk melatih warga lokal membuat dormitory, yang 
merupakan seperti homestay dengan standar hotel bintang tarif kelas melati. Bupati tidak menggusur warga dengan sewenang-wenang, dia mau berdialog untuk menemukan solusi bagi warga. Dia punya kapasitas kepemimpinan jauh di atas kepala daerah lainnya. Contoh konkret yang dilakukan oleh Bupati Banyuwangi, Azwar Anas adalah tidak memberikan izin pendirian minimart di wilayahnya untuk melindungi pedagang kecil tradisional. Dia membuat kebijakan Banyuwangi e-mall untuk membantu para pedagang dalam menjual produk mereka secara online. Meski pilkada langsung banyak terjadi korupsi politik (money politics), tapi juga menghasilkan beberapa pemimpin daerah yang berkualitas.

\section{Rumusan Masalah}

Dari latarbelakang di atas, rumusan masalahnya adalah. (1) Banyaknya kepala daerah yang terjerat dalam kasus korupsi telah berdampak terhadap tingginya angka golput di kalangan pemilih. (2) Tingginya angka golput telah berdampak terhadap legitimasi kepala daerah dianggap tidak memenuhi kriteria bahwa dia telah terpilih secara demokratis. (3) Angka golput yang rata-rata mencapai di atas $30 \%$, di beberapa daerah telah mencapai $40 \%$ keatas bahkan ada yang di atas $50 \%$ semakin mengakibatkan, masalah golput tidak bisa diatasi dengan pemilihan langusng.(4) Pemilihan umum kepala daerah (pemilukada) langsung tidak menjadikan kehidupan masyarakat jadi lebih baik sebagai dampak tingginya money politics, yang berdampak terhadap tuntutan untuk bisa memenuhi kewajiban itu dengan turut sertanya para bandar dan mafia, sehingga kepala daerah seringkali harus memenuhi kewajiban balas budi permodalan yang digunakan dengan melakukan tindak pidana korupsi. (5) Sejauhmana masyarakat mengetahui dan memahami pelaksanaan pemilukada langsung. (6) Apakah banyak masyarakat yang menjadi pemilih setuju terhadap penerapan pemilukada langsung, yang berdampak terhadap pelaksanaan pembangunan di daerah mereka? (7) Bagaimana sebenarnya implementasi pemilukada langsung bisa 
diterapkan di suatu daerah? (8) Bagaimana pemahaman masyarakat tentang pemilukada langsung?

\section{Teori Hirarki Pengaruh}

Dalam asumsi dari teori hirarki pengaruh isi media adalah bagaimana isi pesan media yang disampaikan kepada khalayak adalah hasil pengaruh dari kebijakan internal organisasi media dan pengaruh dari eksternal media itu sendiri. Pengaruh internal pada konten media sebenarnya berhubungan dengan kepentingan dari pemilik media, individu wartawan sebagai pencari berita, rutinitas organisasi media. Sedangkan faktor eksternal yang berpengaruh pada konten mediaberhubungan dengan para pengiklan, pemerintah masyarakat dan faktor eksternal lainnya.

Teori hirarki pengaruh isi media diperkenalkan oleh Pamela J. Shoemaker dan Stephen D. Reese (1996:60). Teori ini menjelaskan tentang pengaruh terhadap isi dari dari suatu pemberitaan media oleh pengaruh internal dan eksternal. Shoemaker dan Reese membagi kepada beberapa level pengaruh isi media, yaitu pengaruh dari individu pekerja media (individual level), pengaruh dari rutinitas media (media routines level),pengaruh dari organisasi media (organizational level), pengaruh dari luar media (outside media level), dan yang terakhir adalah pengaruh ideologi (ideology level).

Asumsi dari teori ini adalah bagaimana isi pesan media yang disampaikan kepada khalayak merupakan hasil pengaruh dari kebijakan internal organisasi media dan pengaruh dari eksternal media itu sendiri. Pengaruh internal pada konten media sebenarnya berhubungan dengan kepentingan dari pemilik media, individu wartawan sebagai pencari berita, rutinitas organisasi media. Sedangkan faktor eksternal yang berpengaruh pada konten media berhubungan dengan para pengiklan, pemerintah masyarakat dan faktor eksternal lainnya. 
Stephen D. Reese (1991:107) mengemukakan bahwa isi pesan media atau agenda media merupakan hasil tekanan yang berasal dari dalam dan luar organisasi media. Dengan kata lain, isi atau konten media merupakan kombinasi dari program internal, keputusan manajerial dan editorial, serta pengaruh eksternal yang berasal dari sumber-sumber non media, seperti individu-individu berpengaruh secara sosial, pejabat pemerintah, pemasang iklan dan sebagainya.

Dari teori ini kita bisa kita lihat seberapa kuat pengaruh yang terjadi pada tiap-tiap level. Walaupun level organisasi media atau faktor kepemilikan sebuah media tapi kita tidak bisa mengesampingkan faktor yang lainnya karena saling terkait satu dengan yang lainnya. Contohnya pengaruh level ideologi yang terjadi pada sebuah isi sebuah media, walaupun dianggap abstrak tapi sangat mempengaruhi sebuah media karena brsifat tidak memaksa dan bergerak di luar kesadaran keseluruhan organisasi media itu sendiri. Untuk lebih lengkapnya selanjutnya kita akan membahas teori hirarki pengaruh media ini berurutan mulai dari level pengaruh individu pekerja media.

\section{Level Pengaruh Individu Pekerja Media}

Pada hakekatnya manusia adalah makhluk yang dilahirkan dalam keadaan lemah dan tidak berdaya, namun dengan demikian ia telah mempunyai potensi bawaan yang bersifat laten, memilki potensi untuk berkomunikasi (Subqi, 2016:165). Pemberitaan suatu media dan pembentukan konten media tidak terlepas dari faktor individu seorang pencari berita atau jurnalis. Arah pemberitaan dan unsur-unsur yang diberitakan tidak dapat dilepaskan dari seorangjurnalis. Pada pembahasan kali ini kita akan mendiskusikan tentang potensi yang mempengaruhi isi dari sebuah media massa dilihat dari faktor intra seorang jurnalis. Faktorfaktor seperti faktor latar belakang dan karakteristik dari seorang pekerja media atau jurnalis, perilaku,nilai dan kepercayaan dari seorang jurnalis dan yang terakhir adalah orientasi dari seorang jurnalis. 
Faktor latar belakang dan karakteristik dari seorang pekerja media menurut Shoemaker dan Reese dibentuk oleh beberapa faktor yaitu masalah gender atau jenis kelamin dari jurnalis, etnis, orientasi seksual,faktor pendidikan dari sang jurnalis dan dari golongan manakah jurnalis tersebut, orang kebanyakan atau golongan elit (Shoemaker dan Reese, 1996:64).

\section{Level Rutinitas Media}

Pada level ini mempelajari tentang efek pada pemberitaan dilihat dari sisi rutinitas media. Rutinitas media adalah kebiasaan sebuah media dalam pengemasan dan sebuah berita. Media rutin terbentuk oleh tiga unsur yang saling berkaitan yaitu sumber berita (suppliers), organisasi media (processor), dan audiens (consumers). Ketiga unsur ini saling berhubungan dan berkaitan yang pada akhirnya membentuk rutinitas media yang membentuk pemberitaan pada sebuah media.

Sumber berita atau suppliers adalah sumber berita yang didapatkan oleh media untuk sebuah pemberitaan. Organisasi media atau processor adalah bisa dikatakan redaksi sebuah media yang mengemas pemberitaan dan selanjutnya dikirim kepada audiens. Dan yang terakhir adalah audiens atau consumer adalah konsumen sebuah berita di media yaitu bisa jadi pendengar, pembaca atau penonton.

Menurut Reese ada beberapa nilai berita yaitu faktor pentingnya sebuah pemberitaan (importance), faktor kemanusiaan (human interest), faktor konflik atau kontroversi pada sebuah pemberitaan (conflict) controversy), faktor ketidakbiasan sebuah berita yang diberitakan (the unusual), faktor keaktualan sebuah berita (timeliness), dan terakhir faktor kedekatan sebuah pemberitaan dengan audiens (proximity) (Shoemaker dan Reese, 1996:64). Keenam nilai berita yang dipaparkan diatas berkaitan dengan rutinitas media berkaitan dengan audiens atau pembaca dari sebuah media pemberitaan. Seperti apa yang telah diungkapkan oleh Schesinger yang dikutip oleh Shoemaker dan Reese. Produksi rutinitas mewujudkan 
asumsi tentang audiens. "Penonton" adalah bagian dari cara dirutinkan kehidupan. Ketika datang untuk berpikir tentang jenis berita yang paling relevan dengan "penonton" wartawan melakukan penilaian berita mereka daripada pergi keluar dan mencari informasi spesifik tentang komposisi, ingin atau selera dari mereka yang sedang ditangani.Jadi, audiens atau pembaca adalah sudah menjadi rutinitas sebuah media. Ini dikarenakan pemilihan sebuah pemberitaan dan pengemasan mengikuti selera dari pembaca atau audiens. Ini berkaitan dengan keuntungan sebuah media yang bergantung pada audiens (Shoemaker dan Reese, 1996:114).

Media juga mempunyai tugas dalam mengemas suatu pemberitaan menjadi sebuah struktur cerita. Pada media cetak contohnya sebuah cerita pada media cetak harus mudah dibaca (readable), foto pada sebuah berita harus memiliki kaitan dengan sebuah cerita pada sebuah media cetak dan judul pada sebuah headline harus memberikan perhatian langsung audiens terhadap sebuah pemberitaan. Sebuah cerita pada pemberitaan merepresentasikan proses rutinitas "apa yang sedang terjadi" dan membimbing reporter untuk menentukan mana fakta yang bisa ditransformasikan menjadi sebuah komoditas pemberitaan.

Di sisi lain media pun diharuskan untuk selalu membuat pemberitaan yang objektif, faktual dan terpercaya. Menurut Michael Schudson para reporter wajib menghibur audiens di satu sisi dan memberikan pemberitaan yang faktual pada satu sisi. Karena sebuah objektifitas pada sebuah media membantu sebuah media melegitimasi dirinya. Ini berkaitan dengan kredibilitas sebuah media yang membuat sebuah pemberitaan (Schudson, 1987:78).

Jadi, pemberitaan sebuah media juga tidak selalu mengikuti apa kemauan dari audiens tapi juga mengikuti fakta-fakta apa saja yang berkembang di lapangan, dan inilah yang mebentuk pembentuk pemberitaan sebuah media pada unsur audiens di level media rutin.Unsur selanjutnya yang membentuk level rutinitas media adalah organisasi media atau 
pengolah pemberitaan (processor). Unsur yang paling berpengaruh pada organisasi media adalah editor media atau yang biasa disebut sebagai gatekeeper. Editor pada setiap media adalah yang menetukan mana berita yang layak untuk diterbitkan atau tidak. Hasil pencarian berita oleh wartawan diputuskan oleh editor di meja redaksi. Jadi editor lah yang menetukan mana berita yang layak terbit. Kebijakan dari editor lah yang menetukan rutinitas sebuah media dalam menentukan pemberitaan.

Jenis media pun mempengaruhi rutinitas sebuah media yang pada akhirnya berpengaruh pada isi dari media. Contoh yang paling menonjol adalah perbedaan antara media cetak dengan media penyiaran seperti televisi. Para pencari berita media cetak lebih bebas dalam memberikan warna pada pemberitaannya. Ini dikarenakan media cetak terbit sekali sehari dan tidak ada tuntutan untuk memberitakan sebuah berita secara langsung. Sedangkan reporter televisi lebih terpaku dalam memberitakan sebuah berita. Biasanya seorang reporter memberitakan langsung dari tempat kejadian dan hanya bersifat melaporkan.

Unsur lain dalam rutinitas media adalah sumber berita. Sumber berita adalah dimana berita didapatkan oleh para pencari berita. Sumber berita biasanya adalah lembega pemerintah, swasta, lembaga swadaya masyarakat, partai politik dan lain sebagainya. Lembaga-lembaga ini dapat mempengaruhi pemberitaan sebuah media dikarenakan, kadang lembaga-lembaga ini memberikan pesanan agar berita yang keluar dari sebuah media tidak bertentangan dengan lembaganya.

Walaupun sumber berita tidak terlalu berdampak signifikan pada konten dari sebuah media, tetapi ketergantungan sebuah media dengan sebuah berita sedikit banyak dapat mempengaruhi sebuah pemberitaan. Biasanya terjadi simbiosis mutualisme antara antara sumber berita dengan media yang mencari berita. Sebuah media mendapatkan bahan berita dengan mudah sedangkan sebuah lembaga mendapatkan pencitraan yang baik tentang lembaganya. 
Rutinitas dari sebuah media memiliki pengaruh yang penting pada produksi isi simbolik. Mereka membentuk lingkungan dimana pekerja media melaksanakan pekerjaannya. Dan pengaruh rutinitas ini berpengaruh secara alami karena bersifat keseharian dan terkesan tidak memaksa pekerja media.

\section{Level Pengaruh Organisasi}

Level ketiga dalam teori hirarki pengaruh media ini merupakan level organisasi media. Pada tingkatan ini kita akan membahas pengaruh organisasi pada sebuah media kepada sebuah pemberitaan. Dan kita akan membahas seberapa kuat pengaruh pada level organisasi pada sebuah pemberitaan. Level organisasi ini berkaitan dengan struktur manajemen organisasi di sebuah media, kebijakan sebuah media dan tujuan sebuah media.

Berkaitan denganlevel sebelumnya pada teori hirarki pengaruh yaitu level individu dan level media rutin, level organisasi lebih berpengaruh dibanding kedua level sebelumnya. Ini dikarenakan kebijakan terbesar dipegang oleh pemilik media melalui editor pada sebuah media. Jadi penentu kebijakan pada sebuah media dalam menentukan sebuah pemberitaan tetap dipegang oleh pemilik media. Ketika tekanan datang untuk mendorong, pekerja secara individu dan rutinitas mereka harus tunduk pada organisasi yang lebih besar dan tujuannya (Shoemaker, 1996:140).

Pengaruh dari level organisasi ini lebih besar dibandingkan dua level sebelumnya dikarenakan berhubungan dengan sesuatu pengaruh yang lebih besar, lebih rumit dan struktur yang lebih besar. Kebijakan dari pimpinan sebuah organisasi media lebih kuat dibanding level lebih rendah yang meliputi pekerja media dan rutinitas.

Berkaitan dengan struktur dan kebijakan sebuah organisasi dari sebuah media tentunya berkaitan pula dengan tujuan dari sebuah media. Tujuan dari sebuah media pada sistem ekonomi kapitalis tentunya erat 
kaitannya dengan profit. Seperti apa yang dikatakan oleh Shoemaker dan Reese bahwa nilai kepercayaan mendasar pada sistem ekonomi kapitalis adalah kepemilikan individu, untuk melampaui target yang yang diinginkan berkaitan dengan kepentingan pengusaha dan pasar bebas. Tujuan dari profit ini selain untuk menggerakkan roda organisasi dan kelangsungan sebuah media juga berkaitan dengan keuntungan yang akan didapat dari sebuah media (Shoemaker, 1996:140).

\section{Level Pengaruh Luar Organisasi Media}

Pada level keempat menurut teori hirarki bahwa pengaruh media adalah level pengaruh dari luar organisasi media atau yang biasa disebut extra media level. Extra media level sendiri merupakan pengaruh pada isi media yang berasal dari luar organisasi media itu sendiri. Pengaruh dari media tersebut berasal dari sumber berita yang ada, pemberi iklan dan penonton, kontrol dari lembaga penyiaran yang ada, pangsa pasar dan teknologi. Peranan manusia dalam mencapai tujuan tersebut sangat penting untuk pencapaian tujuan organisasi dalam media (Mukti Ali, 2016:206).

Dalam pembahasan pengaruh extra media dari unsur sumber berita. Sumber berita memiliki dampak yang besar pada konten sebuah media massa, oleh karena itu seorang jurnalis tidak bisa menyertakan pada laporan beritanya saja. Misalnya seorang jurnalis tidak pernah menjadi saksi mata pada sebuah kecelakaan pesawat terbang. Sehingga dalam mendapatkan berita mereka harus konfirmasi dari sumber berita dan jurnalis lainnya, serta aparat yang bertugas di lokasi kejadian.

Dari penjelasan di atas memberikan gambaran bahwa media yang diberitakan oleh seorang juranlis dapat dibentuk oleh sumber berita. Oleh karena itu sudut pandang yang berbeda dari sumber berita itu sendiri. Kemudian sumber berita juga akan menjadi bias bagi pembuat berita sebab sumber berita bisa bohong terhadap seorang jurnalis dalam sebuah wawancara yang dilakukan. 
Unsur selanjutnya dari level extra media adalah unsur pengiklan dan pembaca. Unsur ini sangat mempunyai dampak yang sangat besar terhadap level ekstra media karena iklan dan pembaca adalah penentu kelangsungan sebuah media, kedua unsure inilah yang membiayai jalannya produksi dan sumber keuntungan dari sebuah media.

Sebuah konten dari pers secara langsung berhubungan dengan kepentingan yang membiayai suatu media. Media tersebut diibaratkan sebagai peniup terompet, dan suara dari teromper itu dikomposisikan oleh orang yang membiayai peniup terompet. Ini merupakan bukti secara substansial bahwa isi dari media secara langsung maupun tidak langsung dipengaruhi oleh pengiklan dan pembaca (Shoemaker, 1996:178).

Pengaruh pemasangan iklan juga terlihat pada isi media yang sudah dikonsep sedemikian rupa, sehingga memiliki pola-pola yang sama dengan pola konsumsi target konsumen. Media dalam hal ini mencoba menyesuaikan pola yang konsumen yang ingin dicapai oleh para pengiklan supaya mendapatkan keuntungan sangat besar. Pemasang iklan menggunakan kekuatan modalnya yang membiayai sebuah media, agar konten dari media tidak bertentangan dengan kepentingan citra terhadap produknya.

\section{Level Pengaruh Ideologi}

Pada level yang terakhir teori hirarki pengaruh Pamela J. Shoemaker dan Stephen D. Reese adalah level pengaruh ideologi pada konten media. Dalam level ini kita membahas ideologi yang diartikan sebagai kerangka berpikir tertentu yang digunakan oleh individu untuk melihat realitas serta bagaimana mereka menghadapinya. Berbeda dengan level pengaruh media sebelumnya yang tampak konkret, level ideologi ini abstrak. Level ini berhubungan dengan konsepsi atau posisi seseorang dalam menafsirkan realitas dalam sebuah media (Littlejohn, 2009:469).

Sebelum membahas lebih jauh mengenai level pengaruh ideologi ini, kita akan membahas terlebih dahulu pengertian ideologi itu sendiri. Ideologi menurut pandangan teori kritis adalah sekumpulan ide-ide yang 
menyusun sebuah kelompok nyata, sebuah representasi dari sistem atau sebuah makna dari kode yang memerintah bagaimana individu dan kelompok memandang dunia. Dalam Marxisme klasik, ideologi adalah sekumpulan ide-ide keliru yang diabadikan oleh ide yang dominan. Dalam pandangan Marxis klasik, ideologi hanyalah ide-ide atau pemahaman yang digunakan oleh kelas yang dominan untuk menanamkan kesadaran palsu bagi kelas yang tertindas untuk melanggengkan kekuasaannya.

Ada tiga definisi ideologi menurut seorang pakar cultural studies Raymond Williams yang dikutip oleh Eriyanto, ideologi adalah sebuah sistem kepercayaan yang dianut oleh kelompok atau kelas tertentu, sebuah sistem kepercayaan yang dibuat ide palsu atau kesadaran palsu, proses umum produksi makna dan ide (Eriyanto, 2009:1).

Terdapatbeberapa kesamaan definisi tentang ideologi menurut para pemikir Marxis klasik dengan Raymond Williams. Keduanya memandang bahwa ideologi adalah sistem artikulasi makna yang dikuasai oleh kelompok dominan yang dibuat ide palsu atau kesadaran palsu. Pada level ini kita akan membahas apa kepentingan yang berperan pada level lainnya terutama level yang berhubungan erat dengan kekuasaan sebuah media yaitu level organisasi media dan level rutinitas media. Pada level ini kita juga mempelajari hubungan antara pembentukan sebuah konten media nilai-nilai, kepentingan dan relasi kuasa media.

Pada level ideologi ini kita melihat lebih dekat pada kekuatan di masyarakat dengan mempelajari bagaimana kekuatan yang bermain di luar media. Kita berasumsi bahwa ide memiliki hubungan dengan kepentingan dan kekuasaan, sampai kepada simbol kekuasaan yang tidak netral. Tidak hanya berita tentang kelas yang berkuasa tetapi struktur berita agar kejadiankejadian diinterpretasi dari perspektif kepentingan yang berkuasa.

Jadi pada level ini kita berbicara lebih luas mengenai bagaimana kekuatan-kekuatan yang bersifat abstrak seperti ide mempengaruhi sebuah media terutama ide kelas yang berkuasa. Pada level ini pun kita 
akan melihat bagaimana kaitan antara level ideologi dengan level-level lainnya. Tetapi kita melihat lebih jauh bagaimana ideologi kelas yang berkuasa mempengaruhi sebuah pemberitaan bukan dengan kepentingan yang bersifat individu atau yang bersifat mikro tetapi kepentingan kelas yang berkuasa.

\section{Media dan Kontrol Sosial}

Media sebagai salah satu agen perubahan sosial, juga memiliki kemampuan untuk memberikan penafsiran atau dapat mendefinisikan situasi yang membuatnya memiliki kekuatan ideologi. Ini berkaitan erat dengan media dengan kekusaan, karena media dapat mentransmisikan bahasa yang dapat melanggengkan kelompok yang berkuasa (Santoso, 2010:24). Hegemoni dari ide-ide pun hanya dapat berjalan efektif dan menemukan kekuatannya tatkala ia menggunakan bahasa hanya sebagai alat dominasi, sekaligus alat represif. Media memilki kekuasaan ideologis sebagai mekanisme ideologi sosial dan fungsi kontrol sosial.

Sebagai salah satu agen perubahan pada sebuah masyarakat, media memiliki fungsi untuk mendefinisikan sebuah penyimpangan di masyarakat. Jika dilihat dari pandangan teori interaksionisme simbolik, penyimpangan dipandangan bukan sebagai perubah kondisi masyarakat tetapi secara bertahap menjadi definisikan dan renegosiasi sebagai peserta dalam sebuah interaksi dengan simbol yang lainnya. Dalam hal ini media memiliki kemampuan untuk memberikan batasan terhadap ide baru, menegaskan kembali norma yang sebelumnya berlaku dan mendefinisikan batasan dalam masyarakat (Shoemaker dan Reese, 1996:225).

Walaupun pada perjalanannya media dengan kemampuanmen definisikan sebuah penyimpangan tidak hanya sebagai alat untuk menyampaikan label penyimpangan yang dibuat oleh kelompok lain di luar media. Melampaui itu semua media memiliki keputusan tersendiri dalam hal mendefinisikan sebuah penyimpangan. 
Dalam membuat sebuah berita media memiliki beberapa kiteria pemberitaan yang berkaitan dengan penyimpangan seperti seberapa besar kontroversi sebuah berita, seberapa tampak sebuah berita dan faktor ketidakbiasaannya sebuah berita. Serta faktor ini menjelaskan sekali bahwa media dapat mendefinisikan sebuah penyimpangan.

Namun, media dalam kemampuannya mendefinisikan sebuah penyimpangan, selalu berada di pihak yang berkuasa. Sebagai agen kontrol sosial, media harus lebih dulu mengidentifikasi ancaman bagi status quo. Dalam sebuah pemberitaan suatu media bisanya justru tidak menyaring sebuah penyimpangan akan tetapi justru menggambarkan penyimpangan sebagai penegasan penyimpangannya (Shoemaker dan Reese, 1996:225).

Gagasan-gagasan yang baru muncul bertentangan atau tidak sesuai dengan penguasa, seringkali didefinisikan sebagai penyimpangan dan saat inilah tugas media difungsikan untuk menjelaskan atau pelabelan penyimpangan pada ide-ide baru tersebut. Situasi ini terjadi karena di satu sisi media memiliki kemampuan untuk mendefinisikan sebuah situasi dan di sisi lain media mendapatkan tekanan dari kekuataan dari luar maupun di dalam media yang mewajibkan media untuk melanggengkan kekuasaan.

Melalui pendekatan yang tidak disadari oleh khalayak ditanamkan ideologi palsu, media dapat menetapkan batasan dan mendefinisikan penyimpangan melalui manipulasi bahasa. Proses penanaman ideologi palsu yang ditanamkan tanpa disadari oleh masyarakat akan dibahas pada pembahasan selanjutnya.

Pada kenyataannya, ideologi satu media dengan media lainnya juga tidak seperti disampaikan hitam atau putih. Perbedaan mendasar itu terletak di siapa yang mendukung siapa dan bukan terkait dengan ideologi karena perbedaan ideologi juga semakin kabur di saat sekarang. Sama dengan partai politik (parpol) yang berbeda hanya namanya saja, tetapi kebijakan yang dilaksanakan ada kemiripan antara satu dengan yang lainnya. 
INJECT (Interdisciplinary Journal of Communication), Vol.3, No.1, Juni 2018: h. 1-22

\section{Hasil Penelitian}

Hasil survei yang telah dilaksanakan dengan sejumlah lembaga survei menyebutkan bahwa sebanyak 15,3 \% warga di Jawa Baratdan Jawa Tengah, yang akan menyelenggarakan Pilkada Serentak pada tahun 2018, menyatakan, sangat setuju dengan pelaksanaan pemilukada secara langsung, sejumlah 40,6 \% setuju, 10,2 \% kurang setuju, 10,7 \% setuju, dan $24,2 \%$ tidak tahu (netral).

Hasil surveimenunjukkan bahwa publik setuju dan sangat setuju dengan penerapan pemilukada langsung mencapai 55,9\%. Sedangkan selebihnya adalah masyarakat yang menyatakan tidak setuju dan sangat tidak setuju dengan penyelenggaraan pemilukada secara langsung di mana jumlahnya mencapai $20,9 \%$, sementara sejumlah $24,2 \%$ responden netral.

Warga mengetahui, sejumlah kepala daerah hasil pemilukada terjerat dengan kasus korupsi. Situasi itu ikut mempengaruhi angka golput yang mencapai $40 \%$, bahkan mencapai $50 \%$ di sejumlah wilayah dalam pelaksanaan pemilukada di Indonesia, khususnya di Jawa Barat dan Jawa Tengah.

Masyarakat mengakses berita terkait pemilukada melalui media massa, media on-line, dan media sosial. Dapat diketahui, sebanyak 27,3 $\%$ masyarakat menyatakan sangat mengakses berita terkait pemilukada melalui sejumlah media tersebut, sebanyak $52,9 \%$ menyatakan mengakses dengan mengakses berita pemilukada melalui sejumlah media, sebanyak 10,7 \% menyatakan kurang mengakses berita pemilukada melalui media, sebanyak 7,8 \% menyatakan tidak mengakses media, dan sebanyak $1,1 \%$ menyatakan tidak tahu.

Terkait dengan peran media massa dalam memberitakan kasus korupsi terkait dengan sejumlah kepala daerah, maka responden menyatakan kasus itu menjadikan mereka sangat kecewa dengan pelaksanaan pemilukada langsung $(9,3 \%)$, kecewa $(46,7 \%)$, tidak kecewa $(27,8 \%)$, kurang kecewa (8,6\%), tidak tahu atau netral $(9,6 \%)$. 
Responden menilai, informasi di sejumlah media massa bermanfaat untuk menjadikan masyarakat mengetahui adanya pemahaman terkait dengan penyelenggaraan pemilukada langsung di mana masing-masing menjawab sangat setuju (7,9\%), setuju (40,5\%), kurang setuju $(36,1 \%)$, tidak setuju (11,2\%), tidak tahuatau netral (0,3\%).

Di samping itu, kesadaran masyarakat terhadap kewajiban warga negara untuk berperan serta mengikuti pemilukada untuk kepentingan pembangunan dapat diketahui sebanyak 10,3\% menyatakan sangat setuju, sebanyak 60,5\% menyatakan setuju, sebanyak 10,9\% menyatakan kurang setuju, sebanyak 11,7 \% menyatakan tidak setuju, dan sebanyak $6,7 \%$ menyatakan tidak tahu atau netral.

Hasil survei memperlihatkan bahwa meski masyarakat tidak setuju terhadap perilaku korupsi yang terjadi dalam sejumlah daerah, mereka tetap masih percaya dengan penyelenggaraan pemilukada secara langsung. Meski demikian, pada umumnya masyarakat menyatakan setuju dengan upaya penindakan yang dilakukan terhadap sejumlah kepala daerah yang melakukan korupsi.

Penyelenggaraan pemilukada langsung dianggap bisa dilaksanakan dan diperlukan dalam penyelenggaraan pemerintahan yang bersih dan transparan. Masyarakat menganggap, pemilihan kepala daerah secara langsung akan bisa memperbaiki kesejahteraan rakyat, tapiberlangsungnya korupsi telah mengakibatkan harapan masyarakat pupus.

Karena itu, masyarakat yang disurvei berharap kepada mereka yang nantinya terpilih menjadi kepala daerah harus merupakan orang-orang yang memang antikorupsi dan selalu berupaya untuk mengutamakan kepentingan publik.

Sementara itu, sejumlah kalangan masyarakat yang merasa lingkungannya dan infrastruktur dalam keadaan rusak menyatakan, mereja kurang setuju dan tidak setuju dengan pemilukada langsung. Sedangkan masyarakat yang menyatakan setuju dan sangat setuju dengan 
pelaksanaan pemilukada secara langsung pada umumnya merasakan bahwa lingkungan mereka dan kesejahteraan mereka lebih baik.

Turunnya Indeks Demokrasi Indonesia (IDI) selama tiga tahun pemerintahan Joko Widodo, menurut Wakil Ketua DPR RI Fadli Zon, mewakili kenyataan yang dirasakan oleh masyarakat. Setidaknya, itulah yang didengarnya saat bertemu dengan konstituen dan masyarakat di daerah lainnya. Fadli Zon, dalam wawancara dengan peneliti, menyatakan bahwa dia melakukan survei terbuka di media sosial (Twitter) tentang kebebasan berpendapat dan berserikat selama tiga tahun pemerintahan Jokowi-JK. Dari 5.193 votes, $78 \%$ berpendapat jika pemerintah makin represif atau otoriter. Hanya 22\% netizen yang menyatakan kita makin terbuka atau demokratis.

Survei ini tidak berbeda dengan survei sejenis lainnya yang dilakukan oleh beberapa media on-line di Twitter sejak beberapa hari lalu. Jadi, ini mewakili gambaran pandangan masyarakat secara umum, bukan hanya di kalangan netizen. Sebab, jika dia turun ke daerah pemilihan atau melakukan kunjungan kerja ke daerah, yang disampaikan masyarakat juga tak jauh berbeda. Kita bukan hanya mengalami penurunan ekonomi, tapi juga kemunduran hukum dan demokrasi.

Misalnya saja, lebih banyak aktivis politik yang ditangkap di zaman Jokowi daripada di zaman SBY. Termasuk, mereka yang ditangkap karena aktivitasnya di sosial media. Tindakan tadi tidak menunjukkan tegasnya penegakkan hukum, tapi menunjukkan kian ketatnya sensor dan tindakan represif oleh pemerintah. Apalagi, di sisi lain pemerintah secara kasat mata juga melakukan standar ganda dalam penegakan hukum.

Aparat banyak menangkap netizen yang membully dan nyinyir terhadap pemerintah, dengan berbagai tuduhan serius, tapi di sisi lain Istana justru mengundang para buzzer yang kerap menulis posting kasar, penuh kebencian, dan juga fitnah terhadap siapapun yang dianggap berseberangan dengan pemerintah. Para buzzer ini terbukti imun. Ini jelas 
sebuah kemunduran, ketika hukum digunakan bukan untuk menegakkan keadilan, tapi hanya untuk melindungi kekuasaan.

Fadli Zon menyatakan, survei-survei yang menyatakan bahwa masyarakat puas atas kinerja pemerintah itu penuh paradoks. Kepuasan masyarakat di berbagai bidang vital, seperti soal harga kebutuhan pokok, kemiskinan, lapangan kerja, atau pengangguran, tingkat kepuasan di bidang-bidang tadi rata-rata di bawah $35 \%$. Bahkan ada yang di bawah $30 \%$. Bagaimana bisa kemudian kepuasaan umum terhadap pemerintah bisa di atas $60 \%$ ?

Ada lompatan logika yang tidak nyambung di situ. Memang itu sebenarnya tidak terlalu mengherankan, karena hampir semua lembaga survei di Indonesia juga merangkap menjadi lembaga konsultan politik dan masyarakat kita sudah makin cerdas memperhatikan hal itu.

Survei ini tidak berbeda dengan survei sejenis yang sudah pernah dilakukan oleh beberapa media on-line di Twitter sejak beberapa waktu dulu. Jadi menurutnya, fenomena ini mewakili gambaran pandangan masyarakat secara umum, bukan hanya di kalangan netizen karena berkenan turun ke daerah pemilihan atau melakukan kunjungan kerja ke daerah, yang disampaikan masyarakat juga tak jauh berbeda bahwa yang dirasakan masyarakat bukan hanya mengalami penurunan ekonomi, tapi juga kemunduran hukum dan demokrasi.

Berikut ini juga disampaikan hasil riset yang dilakukan terkait dengan fenomena kehadiran kepala daerah. Riset ini dilaksanakan di daerah kabupaten Wonosobo, provinsi Jawa Tengah, yang terbilang fenomenal karena pemilukada dimenangkan oleh kalangan juragan kayu. Bupati Wonosobo terpilih merupakan anak dari juragan kayu terbesar di Wonosobo. Akan tetapi yang menarik disini adalah dia tidak bisa apa-apa, bahkan tidak hanya itu dia juga terkendala pada komunikasi verbalnya yaitu gagap ngomong di publik. Sang ayah membeli kursi bupati untuk anaknya, almost literally, dengan mengeluarkan dana sampai Rp 
40 miliar.Berdasarkan data Kemendagri, dari 500 lebih kepala daerah, sebanyak 350 an di antaranya tersandung kasusus korupsi.

Sementara, Bupati Bangkalan yang bapaknya adalah terpidana korupsi. Dia dinilai sebagai bupati 'in absentia' karena tidak pernah ke kantor. Sudah terjadi berbagai gerakan untuk melengserkannya, namun gagal dikarenakan dia bisa membayar hampir semua parpol.Selain itu, juga ada fenomena para penjudi yang bisa ikut bertaruh bahkan memengaruhi hasil pilkada yang terjadi di sejumlah wilayah.

Dalam wawancara peneliti dengan Farid Gaban, seorang wartawan senior, terdapat cerita dan fenomenadi klinik istrinya.Seorang ibu mengaku menolak uang dari calon B. Dengan alasan bahwa dia sudah menerima uang dari calon A. Sebagai orang Islam, dia berpandangan, harus menjaga amanah. Buat dia, dosa kalau mengingkari janji.

Menurut informan, ini adalah contoh dari merasuknya money politics dan pemahaman yang kurang di kalangan masyarakat, tidak tahu bahwa menerima uang dari calon mana saja sebenarnya dosa atau salah. Betul, ada kepala daerah yang progresif dan inovatif. Namun, masih banyak yang belum bagus dan tidak jelas kinerjanya.

Kalau saja ada penelitian mendalam dengan sampel 100 pilkada, kita mungkin bisa mengetahui berbagai masalah dan dicari solusinya. Tidak cuma jajak pendapat kalah menang. Salah satu tugas wartawan adalah untuk tidak terjebak dalam horse racejournalism ketika meliput politik.

Sumber lainnya, Didin Abidin Masud menyatakan, dia terkesan dengan kebijakan progresif di Banyuwangi. Tidak boleh ada buah impor, dengan tujuan supayapetani buah lokal tetap tetap bisa untung. Selain itu hotel berbintang dengan jaringan internasional juga dibatasi. Bahkan mereka diwajibkan untuk menggunakan dana Corporate Social Responsibility (CSR) yang merupakan suatu konsep bahwa organisasi, khususnya perusahaan adalah memiliki berbagai bentuk tanggung jawab terhadap seluruh pemangku kepentingannya, yang di antaranya adalah konsumen. 
Maka untuk melatih warga lokal mendirikan sebuah dormitory, semacam homestay dengan standar hotel berbintang dengan tarif kelas melati. Dengan demikian Bupati tidak menggusur warga dengankewenangan yang dia miliki, dia mau berbincang bersama masyarakat hinggamendapatkan solusi.Dia punyakapasitas kepemimpinan yang memadai. Bupati Banyuwangi, Azwar Anas tidak memberikan izin kepada infestor untuk mendirikan swalayan di wilayahnya karena ingin melindungi pedagang kecil tradisional. Demi keberpihakannya terhadap pedagang kecil Azwar Anas mendirikan Banyuwangi e-mall untuk membantu para pedagang menjual produk mereka secara on-line.

\section{Simpulan}

Berdasarkan riset yang telah diselenggarakan oleh peneliti dapat diketahui bahwa penyajian berita dan informasi di media baik itu media massa (media elektronik dan media cetak), media on-line, dan media sosial itu memengaruhi persepsi, sikap,dan perilaku atau keputusan yang dipilih terkait dengan penyelenggaraan pemilukada secara langsung.

Masyarakat mempunyai harapan bahwa pemilukada langsung dapat memberikan kesejahteraan yang baik untuk daerah, tersedianya lapangan pekerjaan, pendidikan gratis, serta ketersediaan kebutuhan bahan pokok dengan harga yang terjangkau, di samping ketersediaan bahan bakar minyak dan gas yang memadai.

Selain itu, responden menunjukkan bahwa terjadinya sejumlah kasus korupsi di sejumlah daerah yang dilakukan oleh kepala daerah merupakan ekses money politics, namun ada juga sebagian kalangan yang beranggapan bahwa tingginya beban kepala daerah untuk melaksanakan janji kampanye juga mengakibatkan mereka harus melakukan berbagai cara termasuk korupsi untuk memenuhi janji kampanye tersebut.

Sedangkan hirarki pengaruh yang dilakukan oleh organisasi media (lembaga), individu, ideologi, eksternal, dan rutinitas media mempunyai 
peran dalam penyampaian berita tentang pemilukada di media massa, media on-line, dan media sosial. Antusiasme masyarakat, kepentingan rating, dan idealisme saling memengaruhi media untuk membagikan informasi serta pesan yang terkait penyelenggaraan pemilukada langsung.

\section{Daftar Pustaka}

Ali, Mukti. "Eager Exspectation dan Motivasi Mahasiswa Jurusan Komunikasi dan Penyiaran Islam IAIN Salatiga", INJECT (Interdisciplinary Journal of Communication), Vol 1 No 2 Desember 2016.

Eriyanto, 2009. Analisis Wacana, Pengantar Analisis Teks Media. Cet. VII. Yogyakarta: LKiS.

Littlejohn, Stephen W. dan Karen A. Foss. 2005. Theories Of Human Communication, $8^{\text {th }}$ ed. Belmont: Thomson Wadsworth. . 2009. Theories of Human Communication, $9^{\text {th }}$ ed. Jakarta: Salemba Humanika.

Nindito, Stefanus. "Studi tentang Konstruksi Makna dan Realitasdalam Ilmu Sosial Fenomenologi Alfred Schutz", Jurnal Ilmu Komunikasi. Volume 2. Juni 2005.

Santoso, Listiyono dkk. 2010. Epistemologi Kiri. Yogyakarta: Ar-Ruzz Media

Schudson, Michael. 1987. Discovering The News. New York: Basic Books. Shoemaker, Pamela and Reese, Stephen. 1996. Mediating the Message: Theories of Influences on Mass Media Content. 2nd ed. White Plains

Subqi, Imam. "Pola Komunikasi Keagamaan dalam Membentuk Kepribadian Anak", INJECT (Interdisciplinary Journal of Communication), Vol 1 No 2 Desember 2016. 